\title{
IDENTIDADE: uma desconstrução crítica com um esboço de teoria e uma análise da identidade nacional e do caso brasileiro
}

\section{Oto Dias Becker Reifschneider}

Curso: Mestrado em Sociologia

Data de defesa da dissertação: 15 de julho de 2005

Orientadora: Prof ${ }^{a}$ Dr $^{\mathrm{a}}$ Mariza Veloso Motta Santos

\section{Resumo}

O intuito desta dissertação é investigar a identidade em seus dois aspectos: como conceito abstrato e como narrativa. Ao se estudar a identidade em seu primeiro aspecto, utilizou-se principalmente da filosofia e da teoria social para não só investigá-la como também propor, com as tipologias desenvolvidas, a identidade como solução de diversos conflitos entre posições metacríticas.

Num segundo momento, utilizando-se dessas proposições, estudou-se a identidade como trama (narrativa, discurso), tendo como exemplo a identidade nacional e, mais especificamente, a brasileira. Quis-se, ao longo desta dissertação, ressaltar a relação entre teoria e práxis, entre ciência e política.

Palavras-chave: identidade, nacionalismo, teoria crítica, desconstrução, Sociologia, reflexividade. 